\title{
Fecal samples as DNA source for the diagnosis of Necrotizing Hepatopancreatitis (NHP) in Penaeus vannamei broodstock
}

\author{
Boris Briñez, Fernando Aranguren, Marcela Salazar* \\ Centro de Investigaciones de la Acuicultura en Colombia (CENIACUA), Carrera 8A \# 96-60, Bogota, Colombia
}

\begin{abstract}
Necrotizing Hepatopancreatitis (NHP) is a severe disease of cultivated penaeid shrimp caused by a pleomorphic, gram-negative, intracellular rickettsia-like bacterium. Current diagnostic methods for this disease are invasive, requiring dissection of the animal to perform histopathological analysis. In Colombia, NHP affects mainly broodstock, being a major cause of mortalities in maturation laboratories. In order to identify the presence of NHP without having to dissect the animal, we developed a PCR-based method using fecal samples as the DNA source. The DNA was extracted using a quick isolation protocol followed by amplification with primers specific for $16 \mathrm{~S}$ ribosomal RNA gene sequences. To verify the sensitivity and specificity we analyzed samples from the same animal by PCR and in situ hybridization, and found $100 \%$ agreement. In addition, we amplified DNA extracted form paraffin blocks to confirm NHP diagnosis. PCR amplification from fecal samples and paraffin blocks yielded the expected $440 \mathrm{bp}$ fragment. We conclude that PCR amplification from fecal samples is a valuable tool for the diagnosis of NHP in broodstock organisms, and that paraffin-fixed tissues can be used as a source of DNA for PCR amplification of NHP.
\end{abstract}

KEY WORDS: Necrotizing Hepatopancreatitis - Penaeus vannamei · PCR - In situ hybridization - Broodstock - Fecal samples

Resale or republication not permitted without written consent of the publisher

Necrotizing Hepatopancreatitis (NHP) is a disease of cultured Penaeus vannamei caused by an organism which is a gram-negative, intracellular rickettsia-like bacterium (Krol et al. 1991, Frelier et al. 1992, Lightner et al. 1992). NHP was first reported in Texas in 1985 (Johnson 1989), and it is responsible for mortalities in shrimp ponds in Central and South America. The growth and proliferation of NHP within the hepatopancreatic (HP) epithelial cells is associated with the following signs: anorexia, lethargy, abdominal muscle atrophy, softened exoskeleton, growth retardation, and mortalities ranging from 20 to $95 \%$ (Lightner 1996).
As the clinical signs of NHP are nonspecific, the diagnosis is mainly achieved by wet-mount analysis of squashed HP tissue, showing reduced or absent lipid droplets with melanized HP tubules, and by histopathogical analysis with hematoxylin-eosin staining (H\&E). Typical histological features of NHP are HP multifocal granulomatous lesions and atrophy (Lightner 1996). Moreover, NHP is histologically confirmed either by Stenier's stain, in situ hybridization with a complementary labeled DNA probe, or by transmission electronic microscopy (TEM). More recently, PCRbased methods have been successfully utilized for NHP identification (Loy et al. 1996). Although these methods are highly sensitive and specific for NHP confirmation, they require killing the individual to obtain the samples.

In Colombia, NHP affects mainly broodstock rearing ponds and shrimp in maturation laboratories, where destructive, confirmatory diagnosis is not practical because of the high value of the shrimp. This creates the need for non-invasive testing methods. Thus, we studied the efficacy of an NHP-specific PCR detection system using DNA template extracted from shrimp fecal samples. We also tested DNA extracted from paraffinembedded tissues to confirm NHP presence in comparable lesions observed with H\&E, and to validate the extraction method for further retrospective studies.

Materials and methods. Shrimp: Twenty-five Penaeus vannamei, average weight of $35 \mathrm{~g}$, were obtained from farm ponds with clinical signs of NHP and mortalities. Upon arrival to the laboratory, each shrimp was placed in a 401 tank containing filtered seawater. Experimental conditions were temperature $\left(31^{\circ} \mathrm{C}\right)$, salinity $(35 \mathrm{ppm})$, constant aeration and $90 \%$ daily water exchange. Shrimp were fed twice a day with a commercial diet (Purina 35\% protein).

Fecal samples were individually collected for 3 consecutive days, then separated from pelleted food and 
other debris, as previously described (Pantoja \& Lightner 2000), and kept at $-20^{\circ} \mathrm{C}$ until processed. Samples from the same shrimp obtained on different days were pooled for DNA extraction. On Day 4, shrimp were sacrificed, fixed and embedded in paraffin. These samples were used for histology (Bell \& Lightner 1988), in situ hybridization analysis (Lightner 1996) and DNA extraction (Gustincich et al. 1991).

DNA extraction: For DNA extraction from feces we used a previously described protocol for tissue samples (Loy et al. 1996) with the following modifications. In brief, 2 to $3 \mathrm{mg}$ of macerated feces was diluted in $1 \mathrm{ml}$ Tris- $\mathrm{HCl}$ sucrose buffer (33 mM Tris-HCl pH 7.4, $0.25 \mathrm{M}$ sucrose) and centrifuged at $1000 \mathrm{rpm}(500 \times \mathrm{g})$ for $3 \mathrm{~min}$. One hundred $\mu \mathrm{l}$ of supernatant were transferred to a new tube, mixed (v:v) with digestion buffer (100 mM Tris pH 8.0, 2 mM EDTA, 2\% Tween-20, 100 $\mu \mathrm{g} \mathrm{m} \mathrm{m}^{-1}$ Proteinase $\mathrm{K}$ ) and incubated at $60^{\circ} \mathrm{C}$ for $2 \mathrm{~h}$. Proteinase $\mathrm{K}$ inactivation was carried out at $100^{\circ} \mathrm{C}$ for $10 \mathrm{~min}$, and the DNA samples were stored at $4^{\circ} \mathrm{C}$ until used.

For DNA extraction from paraffin-embedded tissues, sections of $10 \mu \mathrm{m}$ were placed in sterile $1.5 \mathrm{ml}$ tubes and deparafinized with $1 \mathrm{ml}$ of xylol for $5 \mathrm{~min}$ followed by washing in $100 \%$ ethanol. After drying to remove the ethanol, the pellet was resuspended in $50 \mu \mathrm{l}$ of lysis buffer (10 mM Tris EDTA, 2\% Tween-20, $500 \mu \mathrm{g} \mathrm{ml}^{-1}$ Proteinase K) and incubated overnight at $60^{\circ} \mathrm{C}$. Proteinase $\mathrm{K}$ inactivation was performed as described above.

PCR reactions: $\mathrm{PCR}$ was carried out in a final volume of $20 \mu \mathrm{l}$ containing $2 \mu \mathrm{l}$ of DNA, $10 \mathrm{mM}$ Tris- $\mathrm{HCl}$ (pH 8.3), $50 \mathrm{mM} \mathrm{KCl}, 1.5 \mathrm{mM} \mathrm{MgCl}, 125 \mu \mathrm{M}$ dNTPs and 5 pmol of each primer, forward pf-1: 5'-ACG-TTGGAG-GTT-CGT-CCT-TCA-g-3' and reverse pr-2: 5'TCA-CCC-CCT-TGC-TTC-TCA-TTG-T-3' (Loy et al. 1996). Samples were subjected to 35 cycles of amplification in a programmable thermocycler Perkin Elmer 2400 , using a 3 step profile: denaturation at $95^{\circ} \mathrm{C}$ for $20 \mathrm{~s}$, annealing at $52^{\circ} \mathrm{C}$ for $30 \mathrm{~s}$ and extension at $72^{\circ} \mathrm{C}$ for $30 \mathrm{~s}$. The final extension step was $72^{\circ} \mathrm{C}$ for $4 \mathrm{~min}$. Amplicons were electrophoresed in $1.5 \%$ agarose gels, stained with ethidium bromide, and photographed under ultraviolet light. A positive result was a band at $440 \mathrm{bp}$.

Amplification of a housekeeping gene was performed separately on NHP PCR-negative samples to insure integrity of the PCR reaction and the presence of shrimp DNA. The primers amplified a $424 \mathrm{bp}$ fragment of the $\beta$-actin genes (GenBank accession number AF300705) foward BA F: 5'-CGA-GGT-ATC-CTC-ACC-CTG-AA3' and reverse BA R: 5'-TGG-TCG-TGA-AGG-TGTAAC-CA-3' in a final volume of $20 \mu$ containing $2 \mu \mathrm{l}$ of DNA, 10 mM Tris-HCl (pH 8.3), $50 \mathrm{mM} \mathrm{KCl}, 1.5 \mathrm{mM}$ $\mathrm{MgCl}_{2}, 125 \mu \mathrm{M}$ dNTPs and 5 pmol of each primer.
For NHP diagnosis, each sample was amplified using both pairs of primers (housekeeping gene and NHP). Diagnosis was considered successful only when amplification with the $\beta$-actin primers was positive.

Histopatology and in situ hybridization: Whole shrimp were fixed in Davidson fixative (Humason 1972) for 24 to $48 \mathrm{~h}$ and routinely processed for histopathological examination with H\&E (Bell \& Lightner 1988). A total of 45 independent samples were analyzed. Of these, 25 samples were obtained from the experimental animals while another 20 were recovered from samples processed between June 2001 and June 2002. All samples showing granulomatous lesions in the hepatopancreas, suggestive of NHP infection, were tested by in situ hybridization using the commercial dioxygenin-labeled probe from DiagXotics, following the manufacturer's protocol.

Results and discussion. Analysis of tissue sections stained with H\&E showed granulomatous lesions and various degrees of HP tubule atrophy in all 25 experimental shrimp, suggestive of NHP infection. These samples were further analyzed by in situ hybridization with a complementary NHP-labeled probe (Fig. 1), which is the confirmatory test used for NHP in our laboratory. By this method, 14 (56\%) out of 25 samples were positive and the other cases (44\%) were negative. These results show the value of the in situ hybridization in its ability to distinguish between HP multifocal granulomas caused by NHP from those caused by other bacterial infections, mainly Vibrio species. It is also possible that some of the granulomas seen by H\&E staining were residual from late stages of NHP disease, when the microorganism had already been eliminated but the lesions persisted.

With extracted DNA from fecal samples parallel to the 25 histopathological samples, PCR amplification with NHP specific primers gave positive results (i.e. expected amplicon of $440 \mathrm{bp}$, Fig. 2) with the same 14 cases that gave positive in situ hybridization results (i.e. $100 \%$ concordance between the 2 tests). NHP or its remnants might be expected in feces since it is found mainly in the hepatopancreas, a part of the gastrointestinal tract. As we considered the in situ hybridization to be our gold standard method, PCR amplification using DNA from fecal samples had 100\% sensitivity and specificity (Table 1). In addition, our results strengthen the feasibility of employing fecal samples for the diagnosis of gastrointestinal pathogens in shrimp as described by Pantoja \& Lightner (2000) for hepatopancreatic parvovirus (HPV).

Although the presence of PCR inhibitors has been well documented in human fecal samples (Miyagi et al. 1999, Cavallini et al. 2000), we did not detect inhibitors even using a simple DNA extraction method (Gustincich et al. 1991). The absence of PCR inhibitors was 


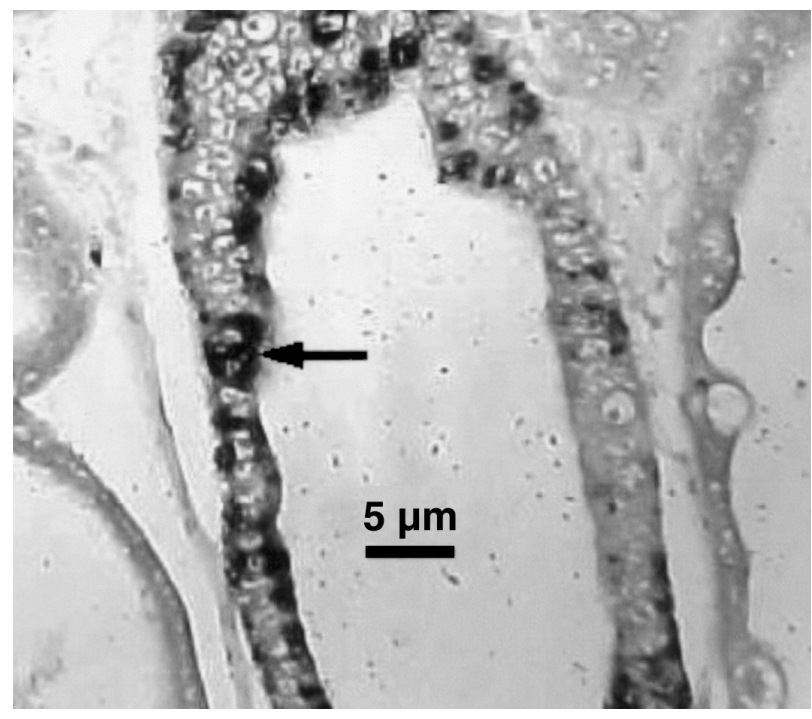

Fig. 1. Necrotizing Hepatopancreatitis (NHP) in Penaeus vannamei. In situ hybridization results of infected hepatopancreatic tissue using the commercial digoxygenin-labeled probe from DiagXotics. Positive cells show a dark coloration (black arrow), while normal cells are stained gray

confirmed by positive PCR results for the $\beta$-actin gene internal control in all samples. This clearly showed that NHP-negative samples were true negatives and not false negatives due to the presence of inhibitors.

PCR tests for the presence of NHP in DNA extracted from 25 paraffin blocks newly prepared from the experimental shrimp gave $15(60 \%)$ positive and 10 (40\%) negative results. Tests with parallel sections by in situ hybridization gave identical results, except for 1 sample that was positive by PCR and negative by in situ
Table 1. Necrotizing Hepatopancreatitis (NHP) in Penaeus vannamei. Correlation of the NHP diagnosis by PCR and in situ hybridization.

\begin{tabular}{|lccc|}
\hline & \multicolumn{3}{c|}{ In situ hybridization } \\
& Positive & Negative & Total \\
\hline Fecal samples & & 0 & \\
PCR positive & 14 & 11 & 11 \\
PCR negative & 0 & 11 & 25 \\
Total & 14 & 1 & \\
Paraffin blocks & & & 20 \\
PCR positive & 19 & 22 & 20 \\
PCR negative & 0 & 19 & 40 \\
Total & & & \\
a The 5 samples that did not amplify with the housekeeping \\
gene are not included & \multicolumn{3}{|c}{} \\
\hline
\end{tabular}

hybridization. Since PCR is much more sensitive than in situ hybridization, this specimen may simply have been too lightly infected to be detected by the latter technique. We also analyzed 20 archived paraffin blocks that had been accumulated over the preceding year. Out of the 20 samples, 5 (25\%) gave no amplicon with the $\beta$-actin housekeeping gene primers, indicating PCR inhibition or lack of sufficient template DNA. However, 2 of these samples were positive and 3 negative by in situ hibridization. Of the remaining 15 samples, 4 were positive for NHP by both PCR and in situ hibridization, while 11 were negative by both tests. The 11 negatives gave positive signals with the housekeeping primers, confirming the integrity of the PCR reactions. These data show that paraffin blocks can be used as a source of DNA to confirm NHP infection by PCR with $100 \%$ sensitivity and $95 \%$ specificity (Table 1 ).

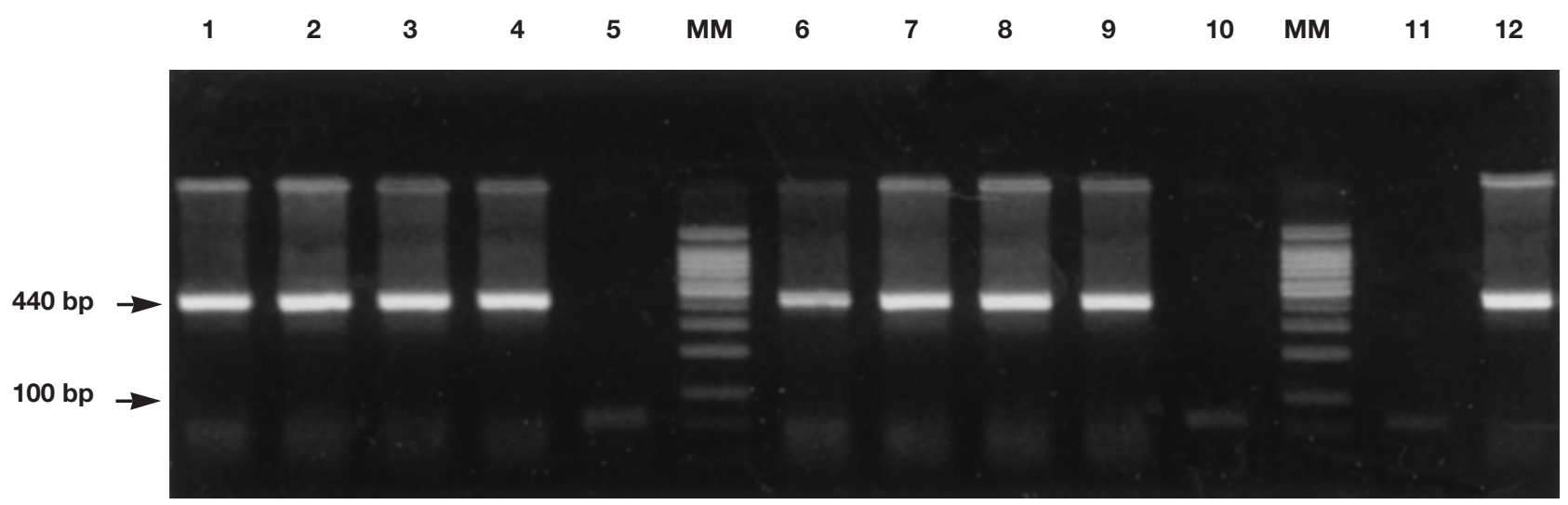

Fig. 2. Necrotizing Hepatopancreatitis (NHP) in Penaeus vannamei. Agarose gel electrophoretic analysis of PCR products from fecal samples and paraffin blocks using primer specific for 16S of NHP (440 bp). MM: molecular marker of $100 \mathrm{bp}$ ladder (arrow shows the $100 \mathrm{bp}$ fragment). Lanes 1-4: positive fecal samples. Lane 5: negative fecal sample. Lanes 6-9: positive samples from paraffin blocks. Lane 10: negative sample from paraffin blocks. Lane 11: no template negative control. Lane 12: NHP-positive control. Negative samples from feces and paraffin blocks were tested separately by PCR using primers specific for shrimp $\beta$-actin and all gave a positive band at $424 \mathrm{bp}$ (not shown) 
DNA extracted from paraffin-embedded tissues is widely used in diagnostic pathology but its major drawback is the DNA degradation (Coombs et al. 1999). Prolonged fixation times and/or the use of some fixatives have been reported to cause permanent damage to the DNA, preventing amplification of fragments longer than $100 \mathrm{bp}$ (Greer et al. 1994). It has also been reported that the low $\mathrm{pH}$ fixatives used for shrimp preservation are not ideal for maintaining DNA and RNA templates (Hasson et al. 1997). We found that 5 out of 45 samples $(11.1 \%)$ from paraffin blocks did not amplify with the internal control primers, confirming the importance of employing internal control primers to assure that the sample is capable of being amplified.

In summary, application of PCR for detection of NHP in fecal samples will allow for the non-destructive identification and removal of NHP-infected broodstock before they are placed in maturation tanks, potentially leading to hatchery contamination. Paraffin sections may also be used as a source of DNA template for PCR to replace in situ hybridization as a confirmatory test of NHP. This method is faster, more economical and easier to perform.

Acknowledgements. This work was supported by the following Colombian Agencies: Colciencias, SENA and the Ministry of Agriculture. Shrimp used in the study were kindly provided by Dr. Sergio Martinez from Cartagenera de Acuacultura.

\section{LITERATURE CITED}

Bell TA, Lightner DV (1988) A handbook of normal shrimp histology. Special publication No 1. World Aquaculture Society, Baton Rouge, FL

Cavallini A, Notarnicola M, Berloco P, Lippolis A, De Leo A (2000) Use of macroporous polypropylene filter to allow identification of bacteria by PCR in human fecal samples. J Microbiol Methods 39:265-70

Editorial responsibility: Timothy Flegel, Bangkok, Thailand
Coombs NJ, Gough AC, Primrose JN (1999) Optimization of DNA and RNA extraction from archival formalin-fixed tissue. Nucleic Acids Res 27:16 e12

Frelier PF, Sis RF, Bell TA, Lewis DH (1992) Microscopic and ultrastructural studies of necrotizing hepatopancreatitis in Texas cultured shrimp (Penaeus vannamei). Vet Pathol 29: 269-277

Greer CE, Wheeler CM, Manos MM (1994) Sample preparation and PCR amplification from paraffin-embedded tissues. PCR Methods Appl 3(Suppl): S113-S122

Gustincich S, Manfioletti G, Del Sal G, Schneider C, Carninci $P$ (1991) A fast method for high quality genomic DNA extraction from whole human blood. Biotechniques 11: $298-300$

Hasson KW, Hasson J, Aubert H, Redman RM, Lightner DV (1997) A new RNA-friendly fixative for the preservation of penaeid shrimp samples for virological detection using cDNA genomic probes. J Virol Methods 66:227-236

Humason GL (1972) Animal tissue techniques, 3rd edn. WH Freeman, San Francisco, CA

Johnson SK (1989) Digestive gland manifestations. In: Johnson SK (ed) Handbook of shrimp diseases. Sea Grant College Program, Texas A\&M University Galveston, p 16

Krol RM, Hawkins WE, Overstreet RM (1991) Rickettsial and mollicute infections in hepatopancreatic cells of cultures Pacific white shrimp (Penaeus vannamei). J Invertebr Pathol 57:362-370

Lightner DV (1996) A handbook of shrimp pathology and diagnostic procedures for diseases of cultured penaeid shrimp. World Aquaculture Society, Baton Rouge, LA

Lightner DV, Redman RM, Bonami JR (1992) Morphologic evience for a single bacterial ethiology in Texas hepatopancreatitis in Penaeus vannamei (Crustacea Decapoda). Dis Aquat Org 13:235-239

Loy JK, Frelier P, Varner P, Templeton JW (1996) Detection of the etiologic agent of necrotizing hepatopancreatitis in cultured Penaeus vannamei from Texas and Peru by polymerase chain reaction. Dis Aquat Org 25:117-122

Miyagi K, Sano K, Morita C, Imura S and 8 others (1999) An improved method for detecting faecal Vibrio cholerae by PCR of the toxin A gene. Med Microbiol 48:883-889

Pantoja CR, Lightner DV (2000) A non-destructive method based on the polymerase chain reaction for detection of hepatopancreatic parvovirus (HPV) of penaeid shrimp. Dis Aquat Org 39:177-182

Submitted: July 2, 2002; Accepted: March 10, 2003

Proofs received from author(s): May 6, 2003 